\title{
GANGGUAN BERBICARA PSIKOGENIK PADA PENDERITA LATAH
}

\author{
M. Wildan ${ }^{1}$, Dian Effendi ${ }^{2}$ \\ ${ }^{1)}$ Fakultas Sastra, Universitas Pamulang, dosen00278@unpam.ac.id \\ ${ }^{2)}$ Fakultas Sastra, Universitas Pamulang, dianeffendi92@gmail.com
}

\begin{abstract}
Abstrak
Bahasa menjadi bagian penting dalam kehidupan, setiap hari manusia menggunakan bahasa sebagai media berkomunikasi. Adapun kelatahan berbicara yang terjadi pada seseorang menjadi faktor penghambat dalam suatu proses komunikasi. Penelitian ini bertujuan untuk menjelaskan bentuk bahasa dan karakteristik berbicara latah pada karyawan men's wear Sogo Plasa Senayan. Penelitian ini menggunakan pendekatan morfosintakasis dengan tujuan agar dapat diketahui bentuk bahasa serta penggunaan profaniti yang menjadi karakteristik berbahasa latah. Dalam pada itu, penelitian ini menyimpulkan bahwa bentuk bahasa latah dapat berupa kata, frasa, klausa dan kalimat. Sementara karakteristik berbahasa latah dapat berupa kata makian seksual dan kata makian ringan.
\end{abstract}

Kata kunci: psikolinguistik, latah, morfosintaksis, profaniti

\section{Pendahuluan}

Bahasa merupakan salah satu rangkaian panjang yang di dalamnya berisi pengertian dan penggambaran dari bahasa itu sendiri. Namun, di luar konteks bahasa ada beberapa hal yang tidak dapat dijelaskan hanya dari pandangan linguistik saja melainkan harus dipandang dari faktor lain dan psikolinguistik salah satu kajian yang dapat digunakan (Steinberg, 1998 : 95).

Dalam penggunaanya banyak sekali ditemukan gangguan bahasa baik dari sisi ekstrinsik maupun intrinsik individu pengguna bahasa. Faktor ektrinsik yang memengaruhi berbicara seseorang ialah getaran, dan suara bising. Sementara itu, faktor yang paling banyak memengaruhi ketidaklancaran berujar yang terkait dengan 
kajian linguistik ialah kegagapan, kelumpuhan syaraf otak, belahan langit langit mulut dan rusaknya alat pendengaran pada manusia.

Gangguan berbicara lain yang yang sering kita jumpai dalam masyarakat ialah gangguan berbahasa psikogenik. Gangguan berbicara psikogenik ialah gangguan berbicara yang dipengaruhi oleh mental atau kejiwaan penutur. Terdapat empat gangguan mental dalam berujar yaitu bebicara manja, berbicara kemayu, kegagapan dan latah. Gangguan berbicara manja yaitu penutur berbicara dengan gaya bahasa manja dengan tujuan untuk menarik perhatian pendengar. Ganggaun berbicara kemayu merupakan gestur maupun perilaku wanita yang berlebihan. Kegagapan merupakan gangguan berbicara tersendat-sendat, seketika berhenti, megulang-ulang kata pertama kemudian dapat menyelesaikan kalimat secara utuh. Dari ke-3 gangguan psikogenik yang sudah dijelaskan, ganggaun berbicara psikogenik terakhir ialah latah.

Menurut Friedman, Claude T.H dalam bukunya yang berjudul "Extraordinary Disorders of Human Behavior", gangguan psikogenik latah adalah gangguan berbahasa yang paling banyak ditemukan di Asia Tenggara terutama Indonesia dan Malaysia. Latah dapat dikategorikan sebagai penyakit individu maupun kelompok masyarakat, kategori latah dapat digambarkan (1) Timbul akibat adanya ketakutan pada penderita akut (2) gejala latah tergantung pada individu maupun sekelompok masyarakat (3) jenis-jenis latah diantaranya : ekolalia, ekopraksia, koprolalia, dan automiatic obedience (4) latah merupakan gejala spontan yang berlangsung secara alami (5) gejala latah timbul karena adanya stimulis yang diberikan kepada penderita latah seperti menggoda, menggelitik maupun mengejutkan penderita (6) dalam beberapa budaya, gangguan psikogenik latah dapat diterima oleh sebagian budaya seperti masyarakat Melayu Indonesia dan Malaysia. (Friedman, 1982 : 224)

\section{Metode Penelitian}


Penelitian yang berkategori penelitian linguistik ini menggunakan metode kualitatif. Metode penelitian kualitatif ialah metode penelitian yang di dalamnya berisi fenomena ataupun kegiatan yang dijadikan sebuah objek kemudian dari penelitian tersebut dikembangkan menjadi bentuk paragraf yang bersifat deskriptif. Dalam penelitan ini, penulis meneliti fenomena gangguan berbahasa psikogenik yang dialami oleh penderita latah yaitu karyawan men's wear Sogo Plaza Senayan. Januari 2018 sampai dengan April 2018 menjadi masa pengambilan data lapangan.

\section{Pembahasan}

Bentuk Bahasa

Terdapat empat bentuk bahasa yang dikaji dalam tulisan ini yaitu bentuk bahasa yang berupa kata, frasa, klausa, dan kalimat. Untuk menjelaskan keempat hal ini berikut disajikan terlebih dahulu fakta kebahasaannya sebagaimana diuraikan pada Tabel 1. Selanjutnya akan diuraikan pada masing-masing bentuk serta sekaligus kolom nomor pada tabel menunjukkan nomor data.

Tabel 1

\begin{tabular}{|c|l|l|l|l|}
\hline No. & \multicolumn{1}{|c|}{ Kata } & \multicolumn{1}{|c|}{ Frasa } & \multicolumn{1}{|c|}{ Klausa } & \multicolumn{1}{|c|}{ Kalimat } \\
\hline 1. & kontoool & botol bocor & kontol lu \\
nyenggol & $\begin{array}{l}\text { eh tetot, eh tetot } \\
\text { kecolok dah } \\
\text { idung gue. }\end{array}$ \\
\hline 2. & Eh tetot tetot & kondor luuu & lampunya mati & $\begin{array}{l}\text { Eh moncrot, } \\
\text { botolnya } \\
\text { moncrot! }\end{array}$ \\
\hline 3. & $\begin{array}{l}\text { eh tetot tetot } \\
\text { tetot }\end{array}$ & - & kontol lu jatuh & $\begin{array}{l}\text { Eh jeblos eh } \\
\text { jeblos kardusnya } \\
\text { jeblos! }\end{array}$ \\
\hline
\end{tabular}




\begin{tabular}{|c|l|l|l|l|}
\hline 4. & Itil & - & memek gue jatuh & $\begin{array}{l}\text { eh ya Allah, eh ya } \\
\text { Allah kaget gue. }\end{array}$ \\
\hline 5. & $\begin{array}{l}\text { Eh dorong, eh } \\
\text { dorong }\end{array}$ & - & - & $\begin{array}{l}\text { Tuh kan memek } \\
\text { gue jatuh lagi. } \\
\text { Hahaha }\end{array}$ \\
\hline 6. & Kontol & - & - & $\begin{array}{l}\text { Ada promo buat } \\
\text { bank Mandiri } \\
\text { nggak sih? }\end{array}$ \\
\hline 7. & Kontol & - & - & $\begin{array}{l}\text { eh kemana lu, } \\
\text { kemana lu? }\end{array}$ \\
\hline 8. & - & - & - & $\begin{array}{l}\text { eh ya Allah bang } \\
\text { Rohman kaki } \\
\text { kalau nggak } \\
\text { dislepang } \\
\text { ditendang dah. }\end{array}$ \\
\hline 9 & - & - & - & $\begin{array}{l}\text { Eh kok monyet } \\
\text { sih? Eh monyet }\end{array}$ \\
\hline
\end{tabular}

\section{Bentuk Bahasa Berupa Kata}




\section{Data 01}

Data 01 diambil pada tanggal 24 Januari 2018, penulis memberikan kejutan dengan menempelkan bagian depan dengkul penulis kepada bagian belakang dengkul Mella. Kemudian Mella dengan spontan mengujarkan kata kontol dengan intonasi rendah dan nada pelan dan tidak terdapat intonasi final pada kata tersebut. Kemudian setelah itu, terdapat beberapa jeda yang diikuti kalimat kirain siapa (saya fikir siapa). Penulis memasukan kata kontol dalam klasifikasi bentuk kata karena saat Mella mendapatkan stimulan, Mella dengan spontan mengujarkan kata kontol dengan nada rendah namun tidak diikuti intonasi final. Oleh sebab itulah, penulis memasukan data tersebut ke dalam klasifikasi kata.

\section{Data 02}

Data 02 terjadi pada tanggal 15 Maret 2018. Saat itu dua karyawati bernama Dwi dan Dian sedang duduk bersila di area loker karyawan, kemudian karena kesemutan mereka berdua berdiri dan secara tidak sengaja pinggang mereka bertumbuk sehingga mengakibatkan Dwi mengujarkan kata Eh tetot tetot. Kata eh dalam bahasa Indonesia memiliki arti kata seruan akibat adanya rasa takjub maupun kaget. Selain itu kata $e h$ ikuti dengan kata unik berupa ujaran tetot yang tidak memiliki makna dalam kamus bahasa Indonesia dan hanya berupa bunyi atau kata unik yang diujarkan oleh pengidap latah.

\section{Data 03}

Data 03 diujarkan oleh karyawati bernama Soleha pada tanggal 17 Maret 2018. Saat itu penulis berlompat dari rak sepatu saat Soleha membuka pintu gudang. Karena terkejut, kemudan Soleha mengujarkan kata eh tetot tetot tetot. Kata eh seperti disebutkan pada data 02 merupakan kata seru yang mengungkapkan rasa takjub maupun kaget. Kata eh juga diikuti oleh kata unik yaitu tetot yang diduplikasi secara utuh sebanyak tiga kali. 


\section{Data 04}

Data 04 penulis dapatkan pada tanggal 15 April 2018. Ketika itu Venna sedang berjalan kemudian bercakap dengan karyawan bernama Dio. Venna yang sedang bertanya kepada Dio secara tidak sengaja sepatunya tersangkut, dengan spontan Venna mengujarkan kata Itil, dengan nada datar dan tidak ada intonasi final pada akhir kata tersebut. Setelah itu baru diikuti dengan kalimat kok lu nggak pengen Nmax?

\section{Data 05}

Data 05 diperoleh pada tanggal 16 April 2018. Salah seorang karyawati bernama Siti sedang berjalan menuju pintu karyawan. Kemudian Siti menarik gagang pintu yang seharusnya dibuka dengan cara didorong. Siti kemudian mengujarkan kata $e h$ dorong, eh dorong. Seperti yang penulis jelaskan pada bagian sebelumnya, kata eh merupakan kata yang menunjukkan rasa kaget atau kagum. Kata $e h$ diikuti dengan kata dorong dan diduplikasi secara utuh sehingga kata eh dorong diujarkan sebanyak dua kali. Pada akhir dua kata tersebut tidak diikuti dengan kata atau kalimat lain. Sehingga data ke 05 penulis masukkan ke dalam data berupa kata.

\section{Data 06}

Data 06 diambil pada tanggal 18 April 2018. Saat itu terdapat dua karyawan bernama Terik dan Ayu dalam ruangan loker. Kemudian Terik dengan sengaja mendorong badan ayu ke depan karena berjalan terlalu lama. Dengan spontan Ayu mengujarkan kata kontol dengan nada sedikit keras namun tidak diikuti dengan intonasi final pada akhir ujaran dan tidak diikuti dengan kata maupun runtutan bahasa lainnya. Oleh karena itu penulis memasukkan data ke 06 ke dalam morfosintaksis bentuk kata.

\section{Data 07}


Data 07 penulis dapatkan pada tanggal 28 Oktober 2018. Seorang karyawan bernama Okky sedang duduk di area loker, kemudian secara tidak sengaja tangan Okky yang berada di lantai terinjak oleh karyawan bernama Erwin. Secara spontan Okky mengujarkan kata kontol dengan nada keras namun tidak disertai dengan intonasi final pada akhir ujaran.

\section{Bentuk Bahasa Berupa Frasa}

Berdasarkan data yang penulis berikan pada Tabel 4.2. terdapat kolom yang menunjukkan mengenai bentuk bahasa berntuk frasa. Maka data yang diklasifikasikan dalam ujaran latah bentuk frasa dapat diuraikan sebagai berikut ini:

\section{Data 08}

Data 08 penulis dapat pada tanggal 15 April 2018. Saat itu, Kristin sedang membawa botol pembersih kaca, kemudian Kristin menyadari bahwa botol yang sedang dibawanya bocor. Secara spontan, Kristin mengujarkan Eh Bocor,bocor, bocor, botol bocor. Frasa botol bocor merupakan frasa nomina yang memiliki makna botol yang dalam keadaan air keluar dari botol tersebut. Runtutan kata botol bocor belum melampaui batas klausa karena botol bocor masih mewakili satu subjek yaitu botol yang bocor.

\section{Data 09}

Data ke 09 penulis dapatkan pada tanggal 24 April 2018. Saat itu, penulis meminta karyawati bernama Dian untuk menempelkan plester penghangat pada bagian punggung. Secara tidak sengaja penulis yang hendak duduk kehilangan keseimbangan sehingga terjerembab. Karena hal tersebut Dian mengujarkan kondor luuu, Lu ngapa jatoh?. Kata kondor lu diujarkan secara panjang dan tidak dengan intonasi final. Kata kondor lu belum melampaui batas predikat sehingga masih memiliki karakteristik sebagai frasa nominal.

\section{Bentuk Bahasa Berupa Frasa}




\section{Data 08}

Data 08 penulis dapat pada tanggal 15 April 2018. Saat itu, Kristin sedang membawa botol pembersih kaca, kemudian Kristin menyadari bahwa botol yang sedang dibawanya bocor. Secara spontan, Kristin mengujarkan Eh Bocor,bocor, bocor, botol bocor. Frasa botol bocor merupakan frasa nomina yang memiliki makna botol yang dalam keadaan air keluar dari botol tersebut. Runtutan kata botol bocor belum melampaui batas klausa karena botol bocor masih mewakili satu subjek yaitu botol yang bocor.

\section{Data 09}

Data ke 09 penulis dapatkan pada tanggal 24 April 2018. Saat itu, penulis meminta karyawati bernama Dian untuk menempelkan plester penghangat pada bagian punggung. Secara tidak sengaja penulis yang hendak duduk kehilangan keseimbangan sehingga terjerembab. Karena hal tersebut Dian mengujarkan kondor lиии, Lu ngapa jatoh?. Kata kondor lu diujarkan secara panjang dan tidak dengan intonasi final. Kata kondor lu belum melampaui batas predikat sehingga masih memiliki karakteristik sebagai frasa nominal.

\section{Bentuk Bahasa Berupa Klausa}

\section{Data 10}

Data 10 diambil pada tanggal 20 Januari 2018. Seorang petugas keamanan bernama Siti sedang duduk di tempat kerja dekat pintu karyawan. Secara tidak sengaja kali dari petugas tersebut mengenai kabel yang terdapat di bawah meja, karena kaget Siti langsung mengujarkan eh kontol lu nyenggol. Jika diuraikan secara morfosintaksis, kontol lu menempati fungsi sebagai subjek yang memiliki kategori frasa nominal, sedangkan nyenggol memiliki fungsi sebagai predikat. Karena memiliki fungsi sebagai subjek dan predikat atau melampaui fungsi predikatif, maka data 10 merupakan klasifikasi bentuk klausa.

\section{Data 11}


Data 11 diperoleh pada tanggal 20 Januari 2018. Pada saat toko ditutup seorang kasir bernama Venna sedang berjalan ke area pintu karyawan dan lampu toko dimatikan karena sudah malam. Karena terkejut dengan lampu yang mati, Venna mengujarkan itil eh itil, lampunya mati. Runtutan kata lampunya mati dapat diklasifikasikan sebagai klausa karena kata lampunya dapat menempati fungsi sebagai subjek, dan mati dapat menempati fungsi sebagai predikat. Oleh karena ke dua kata tersebut melampaui fungsi predikatif maka dapat dikategorikan sebagai klausa.

\section{Data 12}

Data 12 diperoleh tanggal 23 Januari 2018. Kasir bernama Venna sedang berjalan di area toko. Karena terkejut dengan suara benda yang terajatuh, Venna mengucapkan runtutan kata kontol lu jatuh. Jika diuraikan dengan morfosintaksis, kontol lu menempati fungsi sebagai subjek dengan kategori frasa nominal, sedangkan kata jatuh menempati fungsi sebagai predikat. Karena terdapat unsur subjek dan predikat, maka runtutan kata tersebut dapat diklasifikasikan sebagai bentuk bahasa berupa klausa.

\section{Data 13}

Data ke 13 diperoleh pada tanggal 16 Januari 2018. Mella sedang berada di kantin karyawan untuk makan siang. Ketika itu tangan Mella tidak sengaja menjatuhkan botol yang ada di meja makan. Seketika itu Mella mengujarkan memek gue jatuh yang dimaksudkan ialah botol minumannya terjatuh. Memek gue jatuh dapat diklasifikasikan ke dalam bentuk klausa karena memek gue menempati fungsi sebagai subjek dengan kategori frase nominal. Frase tersebut diikuti oleh kata jatuh yang menempati fungsi sebagai predikat. Karena melewati fungsi predikatif, maka runtutan kata tersebut masuk ke dalam kategori klausa.

\section{Bentuk Bahasa Berupa Kalimat}




\section{Data 14}

Data 14 diambil pada tanggal 9 Februari 2018. Ketika itu penulis dan karyawan bernama Mutia sedang di area loker. Penulis menanyakan aroma dari minyak wangi dan meminta Mutia memberikan pendapat mengenai aroma dari minyak wangi tersebut. Secara tidak sengaja, penulis menempelkan ujung botol minyak wangi ke hidung Mutia. Karena terkejut, Mutia mengujarkan kalimat eh tetot, eh tetot kecolok dah idung gue. Runtutan kata kecolok dah idung gue merupakan kalimat pasif dari hidung gue kecolok atau hidung saya tertusuk. Kecolok merupakan verba yang menerangkan, dan hidung gue merupakan nomial yang diterangkan. Pada bagian akhir kalimat terdapat intonasi final berupa kalimat berita atau kalimat yang memberi tahu bahwa hidung dari Mutia telah tertusuk botol parfum.

\section{Data 15}

Data 15 diperoleh pada tanggal 12 Maret 2018. Saat itu karyawati bernama Ayu hendak meminta minyak kayu putih kepada Fiki. Saat hendak mengambil botol tersebut, secara tidak sengaja botol tersebut justru terjatuh ke atas meja. Secara spontan Ayu mengujarkan kalimat eh moncrot, botolnya moncrot. Ujaran tersebut jika diuraikan secara morfosintaksis ialah kata botol menempati fungsi sebagai subjek (nominal), sedangkan moncrot ialah kata tidak baku dari kata muncrat yang berarti menyembur menempati fungsi sebagai predikat. Pada akhir tuturan, intonasi yang diberikan ialah intonasi kalimat berita yang menjelaskan bahwa botol yang akan dipegang oleh Ayu isinya secara tidak sengaja tersembur keluar.

\section{Data 16}

Data 16 diambil pada tanggal 9 April 2018. Ketika itu Mutia sedang bertanya mengenai harga sepatu yang berada di atas tumpukan kardus. Kemudian salah satu kardus terkena tangan Mutia hingga terjatuh ke lantai, karena kejadian tersebut Mutia mengujarkan kalimat eh jeblos eh jeblos kardusnya jeblos. Mutia menduplikasi kata eh jeblos secara utuh sebanyak dua kali diikuti dengan kata kardusnya yang 
menempati fungsi sebagai subjek dan kata jeblos menempati fungsi sebagai predikat. Nada yang digunakan Mutia ialah nada tinggi dengan intonasi final sebagai kalimat berita yang bertujuan memberikan informasi.

\section{Data 17}

Data 17 didapatkan penulis pada tanggal 9 April 2018. Ketika itu Mella sedang berjalan di dalam toko, kemudian penulis berjalan tepat di depan Mella yang sedang melamun. Saat sudah dekat dan hampir menabrak, Mella mengujarkan kalimat eh ya Allah, eh ya Allah kaget gue. Mella menduplikasi runtutan kata eh ya Allah secara penuh sebanyak dua kali kemudian diikuti oleh kata kaget yang merupakan kata sifat atau adjektiva yang menerangkan subjek yaitu gue atau aku.

\section{Data 18}

Data 18 penulis dapat pada tanggal 16 Januari 2016 saat Mella sedang makan di kantin karyawan dan menjatuhkan botol minuman untuk kedua kalinya. Secara spontan Mella mengujarkan tuh kan memek gue jatuh lagi. kata tuh kan berarti menjelaskan atau menegaskan mengenai suatu hal. Memek gue menempati fungsi sebagai subjek dengan kategori frasa nomina, dan jatuh lagi sebagai predikat.

\section{Data 19}

Data 19 diperoleh pada tanggal 18 Januari 2018. Ketika itu penulis menanyakan mengenai promo bank Mandiri kepada kasir dengan kalimat pertanyaan ada promo buat bank Mandiri nggak sih mba?. Kasir tersebut justru menjawab dengan kalimat yang sama yaitu kalimat tanya ada promo buat bank Mandiri nggak sih?. 


\section{Data 20}

Data 20 didapatkan penulis pada tanggal 26 Januari 2018. Ketika itu penulis berpamitan kepada kasir bernama Neneng untuk pulang terlebih dahulu dengan kalimat mpok ayo pulang!. Neneng menjawab kalimat tersebut dengan kalimat tanya yaitu kalimat eh kemana lu, kemana lu?. Neneng menduplikasi kemana lu sebanyak dua kali secara utuh dengan menambahkan kata $e h$ di bagian awal kalimat.

\section{Data 21}

Data 21 didapatkan pada tanggal 8 April 2018 di area loker karyawan. Karyawan bernama Rohman secara tidak sengaja menginjak jari tangan Okky yang berada di lantai. Karena merasa sakit, Okky mengujarkan kalimat pasif yaitu kalimat eh ya Allah bang Rohman kaki kalau nggak dislepang ditendang dah. Kalimat pasif tersebut ditandai dengan negasi tidak.

\section{Data 22}

Data 22 diperoleh pada tanggal 18 Februari 2018. Pada saat itu seorang karyawati bernama Diah sedang melihat layar telpon genggam, ketika itu terdapat film yang berjudul war for the planet of the Apes. Kemudian Diah mengujarkan runtutan kalimat eh kok Monyet sih? eh monyet. Ujaran tersebut diucapkan dengan nada bertanya atau tujuan ingin mendapatkan informasi mengapa dalam film terebut terdapat tokoh monyet. Hal ini ditandai dengan jawaban karyawati bernama Hawa yang menjawab pertanyaan Diah dengan jawaban ya iya, apes itu kan artinya monyet. 


\section{Karakteristik Bahasa}

Tabel 2 menjelaskan karakteristik bahasa yang sekaligus nomor pada kolom menunjukkan nomor data.

Tabel 2

\begin{tabular}{|c|c|c|}
\hline No. & $\begin{array}{l}\text { Kata Makian Seksual } \\
\text { (sexual words) }\end{array}$ & $\begin{array}{l}\text { Kata Makian Ringan } \\
\text { (mild other words) }\end{array}$ \\
\hline 1. & Eh ya Allah memek gue jatuh. & Eh ya Allah memek gue jatuh \\
\hline 2. & Tuh kan memek gue jatuh lagi! & $\begin{array}{l}\text { eh ya Allah bang Rohman, kaki } \\
\text { kalau nggak dislepang, ditendang } \\
\text { dah. }\end{array}$ \\
\hline 3. & $\begin{array}{l}\text { Eh kontol lu nyenggol. eh gue fikir } \\
\text { orang, taunya kabel. }\end{array}$ & eh ya Allah, eh ya Allah kaget gue. \\
\hline 4. & Itil eh itil, lampunya mati. & - \\
\hline 5. & kontoool. kirain sapa! & - \\
\hline 6. & Itil! Kok lu nggak pengen Nmax? & - \\
\hline 7. & Kontol & - \\
\hline 8. & $\begin{array}{l}\text { Kontol } \\
\text { Ih bang Erwin kaga liat apa } \\
\text { tangan? }\end{array}$ & - \\
\hline
\end{tabular}

Karakteristik Kata Makian Seksual (Sexual Word)

\section{Data 23}

Data 23 penulis dapatkan tanggal 16 Januari 2018. Seorang karyawati bernama Mella sedang makan di kantin karyawan. Secara tidak sengaja Mella menjatuhkan botol minuman kemudian mengujarkan kalimat eh ya Allah memek gue 
jatuh. Yang dimaksud Mella yaitu botol minuman yang terjatuh, namun karena ujarannya tersebut, ujaran Mella dapat dikategorikan sebagai kata makian seksual atau sexual words karena terdapat kata memek yang berarti alat kelamin wanita. Berdasarkan penyebab ekpresinya, ujaran Mella disebabkan karena rasa terkejut (sureprise) karena botol yang di atas meja secara tidak sengaja terjatuh.

\section{Data 24}

Data 24 diperoleh tanggal 16 Januari 2018, saat itu Mella menjatuhkan botol minuman untuk kedua kali dan mengujarkan kalimat tuh kan memek gue jatuh lagi! Hahaha. Kalimat terebut mengandung ujaran kata makian seksual (sexual words) yaitu kata memek yang memiliki makna alat kelamin pada wanita. Penyebab ekpresi yang ditimbulkan ialah akibat Mella yang merasa terkejut (sureprise) karena botol minumannya terjatuh untuk kedua kalinya.

\section{Data 25}

Data 25 penulis dapatkan pada tanggal 20 Januari 2018. Saat itu kaki seorang petugas keamanan wanita bernama Siti sedang duduk dan kakinya mengenai sebuah kabel yang berada di bawah meja. Secara spontan Siti mengujarkan runtutan kata eh kontol lu nyenggol. eh gue fikir orang, taunya kabel. Seperti yang sudah dijelaskan pada bagian sebelumnya, kata kontol memiliki makna kamus yaitu alat kelamin pria, oleh karena itu ujaran Siti diklasifkasikan ke dalam bentuk kata makian seksual (sexual words). Ujaran yang dikatakan oleh Siti merupakan bentuk ekpresi kaget karena kakinya mengenai kabel, sehingga latar belakang ujaran tersebut ialah sureprise atau terkejut.

\section{Data 26}

Data 26 diujarkan oleh seorang kasir bernama Venna yang sedang berjalan di area toko pada waktu penutupan area toko. Saat lampu dipadamkan, Venna mengujarkan Itil eh itil, lampunya mati. Itil merupakan kata yang mengacu pada alat 
vital atau kelamin pada wanita. Karena terdapat kata yang merujuk pada kata seksual, maka ujaran Venna dalam kajian profaniti diklasifikasikan ke dalam kata makian seksual (sexual words). Ujaran Venna diakibatkan adanya rasa terkejut atau sureprise karena lampu yang secara tiba-tiba dipadamkan.

\section{Data 27}

Data 27 merupakan ujaran dari seorang karyawati bernama Mella pada tanggal 24 Januari 2018. Saat itu penulis mengejutkan Mella dengan cara menempelkan ujung dengkul ke bagian belakang kakinya. Namun Mella justru mengujarkan kontoool. kirain sapa!. Kata kontol diklasifikasikan ke dalam kata makian seksual atau sexual words. Penyebab ujaran tersebut ialah karana rasa kaget atau sureprise.

\section{Data 28}

Tanggal 15 April 2018 data diperoleh dari karyawari bernama Venna yang sedang berbincang dengan Dio sambil berjalan. Karena sepatuya tersandug, maka Venna mengujarkan kalimat Itil! Kok lu nggak pengen Nmax?. Kata itil atau biji kelentit (bagian alat kelamin wanita) dalam kajian profaniti masuk ke dalam sexual words atau makian seksual karena mengandung unsur seksual dalam ujarannya. Ujaran seksual tadi diakibatkan adanya rasa terkejut karena kaki Venna yang tersandung sehingga ekpresi Venna diakibatkan adanya sureprise atau rasa terkejut.

\section{Data 29}

Data 29 diperoleh pada tanggal 18 April 2018. Karyawan bernama Terik mencandai Ayu dengan cara mendorong pada bagian punggungnya, karena terdorong ke depan, Ayu mengujarkan kata kontol yang merupakan bagian seksual dari lakilaki. Kata kontol dalam profaniti masuk ke dalam kategori seksual dikarenakan semua kosa kata seksual merupakan kategori makian seksual (sexual words). Akibat dari 
rasa terkejut atau sureprise merupakan hal yang mengakibatkan ujaran makian seksual tersebut diucapkan oleh Ayu.

\section{Data 30}

Data 30 diperoleh dari karyawan bernama Okky tanggal 28 April 2018. Tanggan Okky yang sedang dilantai tidak secara sengaja terinjak oleh karyawan lain bernama Erwin, Okky kemudian mengujarkan kalimat kontol, ih bang Erwin kaga liat apa tangan? Kata kontol masuk ke dalam kata makian seksual atau sexual words. Kata makian tersebut diakibatkan adanya rasa sakit atau pain sehingga memicu adanya ujaran tersebut.

\section{Karakteristik Kata Makian Ringan (Mild Other Word)}

\section{Data 31}

Data 31 diperoleh pada tanggal 16 Januari 2018 yang diujarkan oleh Mella yang menjatuhkan botol yang berada di atas meja makan. Mella megujarkan kalimat eh ya Allah memek gue jatuh. Dalam ujarannya kata Allah merupakan kata makian ringan dikarenakan kata atau nama-nama tuhan seperti kata God atau Jesus dalam kajian profaniti diklasifikasikan dalam bentuk ujaran makian ringan atau mild other words. Ekpresi Mella yang mengujarkan kata makian terebut karena adanya rasa terkejut atau sureprise karena tanggannya yang secara tidak sengaja menjatuhkan botol minuman yang berada di atas meja.

\section{Data 32}

Data 32 diperoleh pada tanggal 8 April 2018 yang didapatkan dari karyawan bernama Okky yang kakinya tekena kaki karyawan lain yang bernama Rohman. Okky mengujarkan kalimat eh ya Allah bang Rohman, kaki kalau nggak dislepang, ditendang dah. Kata Allah seperti dijelaskan pada data-31 merupakan kata yang 
digolongkan ke dalam kata makian ringan. Ujaran Okky diakibatkan adanya rasa sakit atau pain karena kakinya terkena kaki karyawan lain.

\section{Data 33}

Data terakhir didapatkan dari karyawati bernama Mella pada tanggal 9 April 2018. Mella yang terkejut karena penulis berjalan di depan Mella yang sedang melamun mengakibatkan Mella mengujarkan kalimat eh ya Allah, eh ya Allah kaget gue. Kata Allah dalam keadaan tertentu dapat digolongkan dalam bentuk kata makian ringan atau mild other words seperti dalam keadaan terkejut atau sureprise seperti yang dialami oleh Mella tersebut.

\section{Simpulan}

Pertama, pada penderita latah yang dilakukan penelitian sejak bulan Januari sampai dengan April 2018, penulis menemukan bentuk bahasa yang diujarkan oleh penderita latah sebanyak 22 data. Bentuk bahasa latah terbagi atas terbagi atas 7 data berupa kata, 2 data berupa frasa, 4 data berupa klausa dan 9 data berupa kalimat. Berdasarkan 22 data yang dikelompokan ke dalam bentuk bahasa, terdapat 14 kata $e h$ dalam ujaran latah. Terdapat 7 data yang menunjukan pula bahwa karakteristik bahasa latah pada karyawan men's wear Sogo Plaza Senayan mengulangi atau mereduplikasi kata secara utuh.

Kedua, pada penderita latah yang dilakukan penelitian pada bulan januari sampai dengan April 2018 juga ditemukan 11 data yang masuk dalam kategori kata umpatan atau kata makian. Data berupa kata makian terdapat 11 data yang terbagi atas 8 data berupa kata makian seksual (sexual words) yang masing-masing ialah 4 kata berupa kata kontol, 2 kata berupa kata memek dan 2 kata berupa kata itil. 3 data lainnya ialah kata makian ringan (mild other words) yang semuanya kata Allah. Dari keseluruhan data tadi, terdapat 9 data yang menunjukkan akibat yang menimbulkan 
makian yaitu adanya rasa sureprise atau terkejut, dan 2 data yang menjelaskan akibat yang menimbulkan kata makian ialah adanya rasa sakit atau pain.

\section{Daftar Pustaka}

Chaer, Abdul. 2012. Linguistik Umum. Jakarta: Rineka Cipta. 2003. Psikolinguistik. Jakarta: PT. Asdi Mahasatya.

Dardjowidjojo, Soedjono. 2012. Psikolinguistik: Pengantar Pemahaman Bahasa Manusia. Jakarta: Yayasan Pustaka Obor Indonesia.

Endarwati, Oktiani. 2014. Cacat Sintaksis Keluaran Wicara Pada Anak Penyandang Autis di SD Lab. PGSD Setia Budi dan SD IT Al-Mubarak Rawasari (Suatu Kajian Neurolinguistik). Jakarta: Universitas Negeri Jakarta.

Firtriani.2012.Perilaku Latah Pada Remaja.Depok:Uviversitas Gunadarma.

Friedman, Claude dan Robert Andrew Faguet. 1982. Extraordinary Disorders of Human Behavior. Newyork: A Divinition of Plenum Publishing Corp. Plenum press.

Hagen, Sverre Humberset. 2013. Swearwords and attitude change: a sociolinguistic study. Bergen: University of Bergen.

Hariyanto, Bambang.Dkk. 2013. Perilaku Berbahasa Latah Warga Desa Jatigono Kecamatan Kunir Kabupaten Lumajang. Jember: Universitas Jember.

Hermawan, Nur Fadly.2016. Gangguan Psikogenik Orang “Alay”. Madiun: Sekolah Tinggi Agama Islam Nahdlatul Ulama

Kadir, Hatib Abdul.2009. Menafsir Fenomena Latah Sebagai Emosi Kebudayaan Masyarakat Melayu (Suatu Kajian Psikoantropologi). Yogjakarta: Psikobuana.

Kattopo, Vivi Cristiani. 2016. Manado: Universitas Sam Ratulangi.

Prayascitta, Praba. Dkk. Produksi Kalimat Pada Penyandang Gagap. Malang: Universitas Negeri Malang. 
Steinberg, Danny D. 1993. An Intrduction to Psycholinguistik. United Kingdom: Longman Group UK Limited.

Yudibrata, Karna, Dkk. 1997. Psikolinguistik. Jakarta: Departemen Pendidikan dam Kebudayaan.

Wardiah, Dessy.2014. Psikolinguistik Dalam Kemampuan Berbicara Pada Anak Usia Dini. Palembang: Wahana Didaktika.

Winzeler, R.L.1995. Latah in Southeast Asia: The Sistory and Etnography of Culture-bound Syndrome. New York: Cambridge university Press. 